ISSN: 0377-6395
e-ISSN: 2651-4214
DETERİNER HEKİMLER DERNEĞं

\title{
Bazı tritikale çeşitlerinde farklı olgunlaşma dönemlerinin silolamada fermantasyon özellikleri ve yem değeri üzerine etkileri
}

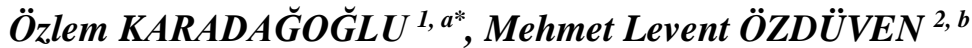 \\ ${ }^{1}$ Kafkas Üniversitesi, Kars Meslek Yüksekokulu, Bitkisel ve Hayvansal Üretim Bölümü,Kars-Türkiye1 \\ ${ }^{2}$ Namık Kemal Üniversitesi, Ziraat Fakültesi, Zootekni Bölümü, Tekirdă̆-Türkiye \\ ORCID: 0000-0002-5917-9565 ${ }^{a}$; 0000-0002-8951-8054 ${ }^{b}$
}

\begin{abstract}
MAKALE BILGISİ /
ARTICLE

INFORMATION:

Geliş / Received:

19 Aralik 18

19 December 18

Kabul / Accepted:

09 Mayis 19

09 May 19
\end{abstract}

Anahtar Sözcükler:

Fermantasyon

Olgunluk dönemi

Tritikale silajı

Yem değeri

Keywords:

Feed value

Fermentation

Maturity stage

Triticale silage
ÖZET:

$\mathrm{Bu}$ çalışma, farklı olgunlaşma dönemlerinde hasat edilen bazı tritikale çeşitlerinin (Karma, Presto ve Tatlıcak-97) fermantasyon özellikleri, besin madde içerikleri ve birim alandan üretilen in vitro sindirilebilir organik madde miktarını belirlemek amacıyla yürütülmüştür. Başaklanma, süt olum ve hamur dönemlerinde hasat edilen tritikale çeşitleri $2 \mathrm{~cm}$ boyutunda parçalanarak 1,0 litrelik yalnızca gaz çıkışına olanak tanıyan özel anaerobik kavanozlara silolanmıştır. Kavanozlar laboratuvar koşullarında $20 \pm 2^{\circ} \mathrm{C}^{\prime}$ de depolanmışlardır. Silolamadan sonraki 75 . günde her gruptan 3 'er kavanoz açılarak silajlarda kimyasal ve mikrobiyolojik analizler yapılmışıı. Ayrıca, enzimatik yöntemle silajların in vitro organik madde sindirilebilirlikleri saptanmıştır. Çalışma sonunda fermantasyon özellikleri, ham besin maddeleri ve hücre duvarı kompozisyonları, birim alandan elde edilen kuru ve organik madde verimleri ve birim alandan elde edilen sindirilebilir organik madde miktarları olgunluk dönemi ve çeşit farklılıklarından önemli derecede etkilendikleri saptanmıştır. Hasat zamanının gecikmesiyle birlikte tritikale silajlarının laktik ve asetik asit ile amonyak azotu, ham protein, ham kül, nötr deterjan lif, asit deterjan lif ve asit deterjan lignin içerikleri azalırken, kuru madde verimleri, $\mathrm{pH}$ değeri ve in vitro organik madde sindirilebilirliklerini ise $\operatorname{artmıştır~}(\mathrm{P}<0,05)$.

\section{Effects of fermentation characteristics and feed value of some triticale cultivars ensiled at different stages of maturity}

ABSTRACT:

This study was carried out to determine the effects of some triticale cultivars (Karma 2000, Presto and Tatlicak-97) harvested at different stages of maturity on the fermentation characteristics, chemical composition and in vitro digestibility organic matter yields. Triticale cultivars were harvested at ear emergence, milk and dough stages of maturity and were ensiled in 1.0 litter special jars equipped with a lid that enabled gas release only. The jars were stored at $20 \pm 2$ ${ }^{\circ} \mathrm{C}$ under laboratory conditions. Silages were sampled for chemical and microbiological analyses on day 75 th after ensiling. In additions in vitro organic matters digestibility of the silages were determined with enzymatic methods. The result of the study indicated that fermentation characteristics, nutritional and cell wall composition, dry and organic matter yield and digestibility organic matters were affected by harvest stage and cultivars. Crude protein, crude ash, neutral detergent fibre, acid detergent fibre and acid detergent lignin contents decreased with increasing maturity of triticale silage whereas dry mater yield, $\mathrm{pH}$ value and in vitro organic matter digestibility increased $(\mathrm{P}<0.05)$.

How to cite this article: Karadağoğlu Ö, Özdüven ML: Bazı tritikale çeşitlerinde farklı olgunlaşma dönemlerinin silolamada fermantasyon özellikleri ve yem değeri üzerine etkileri. Vet Hekim Der Derg, 90 (2): 132-142, 2019. DOI: 10.33188/vetheder.499308

* Sorumlu yazar/Corresponding author

eposta adresi/e-mail address: drozlemkaya@ hotmail.com 


\section{Giriş}

Dünyada ve ülkemizde silaj yapımında yaygın olarak mısır bitkisi kullanılmaktadır. Ancak mısır bitkisinin üretilmesi için yüksek miktarda suya ve belirli bir sıcaklığa ihtiyaç duyulmaktadır (27). Buna karşın kurak koşullarda tek yıllık tahıl hasıllarının ürettikleri birim alanda kuru madde verimi (KMV) oldukça dikkat çekici miktarlara ulaşabilmektedir (23). Tritikalenin çok farklı iklim ve toprak koşullarına adaptasyon yeteneğinin yüksek olması ile diğer serin iklim tahıllarına göre önemli avantajları vardır. Tritikalenin buğday, arpa ve yulaf gibi tahıl cinslerine göre topraktan daha iyi yararlanma yeteneğine sahip olduğunu ve bu nedenle değişen çevre koşullarından daha az etkilendiği bildirilmektedir (19). Özellikle kurak koşullarda diğer serin iklim tahıllarına oranla daha yüksek verim alınabilmektedir. Bunun yanında çavdardan gelen hastalıklara dayanıklılık özelliği, buğday üretimini kısıtladığı alanlarda buğday yerine yetiştirilebilme olanağını sağlamaktadır (16). Buğday tarımına elverişli olmayan toprak derinliği az, çorak, kurak ve kışları çok sert geçen bölgelerde tritikale çeşitleri buğdaydan daha verimli olabilmektedir (26). Hatta asitli topraklarda, yüksek yaylalık yerlerde ve bu yaylaların eteklerindeki taşlı arazilerde tritikale yetiştirilmektedir (7). Tritikale, buğdayla karşılaştıııldığında daha düşük girdi ihtiyacı ile ekonomik ve çevresel avantaja sahiptir. Büyük oranda hastalıklara dayanıklı ve düşük verimli topraklarda az girdi ile yüksek verim elde edilebilme olanaklarına sahip olma özellikleri nedeniyle organik tarım sistemine de en uygun tahıl bitkisidir (20). Ayrıca, oldukça yüksek protein oranı ve iyi bir amino asit dengesine sahip olduğu için buğday ve arpaya göre daha iyi bir hayvan yemi özelliğindedir (15). Büyük oranda tanesi için üretilmesine rağmen, tritikale çift yönlü kullanıma yani bitkinin tane ve diğer kısımlarının kullanımı yönünde de önemli potansiyele sahiptir. Delogu ve ark. (12) tritikalenin özellikle tane veriminin yanında birim alandan yüksek ve kaliteli yeşil ot veriminden dolayı silajlık olarak ilgi çektiğini bildirmektedirler. Albayrak ve ark. (2), süt olum döneminde hasat edilen 62 farklı tritikale hattında kuru madde verimleri (KMV)'nin 838-1893 kg/da arasında olduğunu saptamışlardır. Diğer bitkilerde olduğu gibi tritikale üretiminde yüksek ve kaliteli verim elde edilmesi için bölge koşullarına uygun çeşit seçimi oldukça önemlidir. Ayrıca tritikale silajının yem değeri ile bitkinin hasat edildiği olgunlaşma dönemleri arasında da yakın bir ilişki vardır. Hamur olum döneminde hasat edilen tahıl hasıllarının yem değerinin başaklanma ile süt olum dönemi arasında hasat edilen hasıllardan daha yüksek olduğu bildirilmektedir (33).

$\mathrm{Bu}$ çalışma başaklanma, süt ve hamur olumu dönemlerinde hasat edilen bazı tritikale çeşitlerinin silaj fermantasyon özellikleri, besin madde içerikleri ile bu silajların in vitro organik madde sindirebilirliği (OMS), metabolik enerjisi (ME), birim alandan elde edilen sindirilebilir organik madde verimi (SOMV) ve metabolik enerji verimi (MEV)'nin belirlenmesi amaciyla yürütülmüştür.

\section{Gereç ve Yöntem}

Silaj materyali olarak, Namık Kemal Üniversitesi Ziraat Fakültesi, Tarla Bitkileri Bölümü, araştırma ve uygulama alanında, tesadüf blokları deneme desenine göre üç tekrarlamalı olarak yetiştirilen Karma 2000, Presto ve Tatlıcak-97 tritikale çeşitleri kullanılmıştır. Denemede, her parselde 550 tohum/m2 bitki sıklığında sıra arası $20 \mathrm{~cm}$ ve $5 \mathrm{~m}$ uzunluğundaki 5 sıraya tüm çeşitler ekilmiştir. Tritikaleler ekim ile birlikte $4 \mathrm{~kg} / \mathrm{da}$ saf azot $(\mathrm{N})$ ve $4 \mathrm{~kg} / \mathrm{da}$ saf fosfor (P2O5) gübresi, bitkilerin kardeşlenme döneminde $4.6 \mathrm{~kg} / \mathrm{da}$ saf $\mathrm{N}$ olacak şekilde üre gübresi ve sapa kalkma döneminde $5.2 \mathrm{~kg} / \mathrm{da}$ saf $\mathrm{N}$ olacak şekilde amonyum nitrat gübresi uygulanmıştır.

Araştırmada kullanılan tritikale çeşitleri başaklanma, süt olum ve hamur olumu olmak üzere 3 farklı olgunlaşma döneminde hasat edilmiştir. Hasattan hemen sonra parçalama makinesinde yaklaşı $2 \mathrm{~cm}$ uzunluğunda parçalanmıştır. Parçalanan materyaller 1.0 litre kapasiteli ve yalnızca gaz çıkışına olanak tanıyan özel cam kavanozlara (Weck, Wher-Oftlingen, Germany) 3'er paralelli olarak silolanmışlardır. Kavanozlar, laboratuar ortamında $20 \pm 2$ 0C sıcaklıkta tutulmuşlar ve 75 günlük fermantasyondan sonra açılmışlardır. Araştırmada pH değerleri ise Chen ve ark. (10) tarafindan bildirilen yöntemlere göre saptanmıştır. Silaj örneklerinde amonyak azotu (NH3-N) analizi, silaj örneklerinden elde edilen ekstraklarda mikro distilasyon metoduna (4) göre yapılmıştır. Silajların laktik asit (LA) içerikleri spektrofotometrik yöntem ile (24), asetik asit (AA) ve bütirik asit (BA) içerikleri ise gaz kromotografisi 
cihazında tespit edilmiştir (38). Taze materyalde ve silaj örneklerinde suda çözünebilir karbonhidratlar (SÇK) içeriğgi Anonymus (4) tarafindan bildirilen antron yöntemi ile spektrofotometre cihazında ölçülmüştür. Laktik asit bakterileri (LAB), maya ve küf sayımları Seale ve ark. (34) tarafından bildirilen yöntemler doğrultusunda gerçekleştirilmiştir. Buna göre, ekim ortamı olarak LAB için MRS agar kullanılmıştır. Örneklere ait LAB sayımları 30 0C sıcaklıkta 3 günlük inkübasyon dönemlerini takiben yapılmıştır ve elde edilen sonuçlar daha sonra logaritma koliform ünite (cfu/g)'ye çevrilmiştir. Ham besin maddeleri içerikleri Weende Analiz Yöntemine göre, nötr deterjanda çözünmeyen lif (NDF), asit deterjanda çözünmeyen lif (ADF) ve asit deterjanda çözünmeyen lignin (ADL) analizleri Goering ve Van Soest (18) tarafından bildirilen yöntemlere göre yapılmıştır. Hemiselüloz (Hsel=NDF-ADF) ve selüloz (Sel=ADFADL) hesaplama yolu ile bulunmuştur. Silajların in vitro OMS'nin belirlenmesinde Aufrère ve Michalet-Doreau (6) tarafindan bildirilen enzim metodu uygulanmıştır. Bu amaçla Trichoderma viride mikroorganizmalarından elde edilmiş selülaz enzimi (Merck, Onozuka R10; Germany) ile pepsin enzimi (Merck, 0.7 FIP-U/g, Germany) kullanılmıştır. Selülaz yöntemi ile elde edilen enzimde çözünen veya çözünmeyen OM içerikleri, bazı ham besin maddeleri içerikleri ile silajlar için aşağıda önerilen regresyon eşitliğinden yararlanılarak metabolik enerji (ME) değerleri hesaplanmıştır (5).

$\mathrm{ME}(\mathrm{MJ} / \mathrm{kg} \mathrm{KM})=14.27-(0.012 \mathrm{x}$ enzimde çözünmeyen OM$)+(0.00234$ x HP $)-0.0147 \mathrm{xHK})(\mathrm{ME}:$ Metabolik enerji, OM: Organik maddeler, HP: Ham protein, HK: Ham kül, (* Enzimde çözünmeyen OM içerikleri ile HP ve HK içerikleri g/kg KM'dedir.).

Her parselin kenarlarından 1'er sıra ve sıraların başından ve sonundan olmak üzere 0.5 m'lik kısım biçilerek uzaklaştırılmıştır. Geriye kalan $3.2 \mathrm{~m} 2$ alandaki tüm bitkiler hasat edilmiştir. Elde edilen bitkiler $1 \mathrm{~g}$ duyarlı terazi ile tartılarak parsel verimleri bulunmuş ve daha sonra hesaplama yoluyla dekara yeşil ot verimi (YOV) saptanmıştır. Bitkilerin KM ve OM miktarları kullanılarak dekara KMV ve OMV hesaplanmıştır. Birim alandan elde edilen sindirilebilir organik madde verimi (SOMV), bir dekardan elde edilen toplam OM miktarlarının OMS değerleri ile çarpılmasıyla bulunmuştur. Birim alandan elde edilen metabolik enerji verimleri (MEV) ise örneklerin ME miktarlarının birim alandan elde edilen KMV miktarları ile çarpılarak hesaplanmıştır.

\section{İstatistiksel Analiz}

Araştırmadan elde edilen verilerin istatistiksel değerlendirilmesinde 3 x 3 Faktöriyel deneme desenine göre varyans analizi, gruplar arası farklılığın belirlenmesi ise Duncan çoklu karşılaştırma testi uygulanarak hesaplanmıştır (35). Bu amaçla SPSS 15 (36) paket programı kullanılmıştır.

İstatistiksel model aşağıda gösterilmiştir.

Yijl $=\mu+\tau \mathrm{i}+\gamma \mathrm{j}+\tau \gamma \mathrm{ij}+\mathrm{eijl}$,

$\mu=$ genel ortalama; $\tau \mathrm{i}=$ çeşidin etkisi $\mathrm{i} ; \gamma \mathrm{j}=$ olgunlaşma döneminin etkisi $\mathrm{j}$; $\tau \gamma \mathrm{ij}=$ çeşit $\times_{\text {olgunlaşma dönemi }}$ interaksiyonu; ve eijl =hata.

\section{Bulgular}

Farklı olgunluk dönemlerinde hasat edilen tritikale çeşitlerinin taze materyallerinde saptanan kimyasal ve mikrobiyolojik analiz sonuçları Tablo 1'de verilmiştir. 
Tablo 1: Tritikale çeşitlerinin silolanmadan önce yeşil ot verimi ile kimyasal ve mikrobiyolojik analiz sonuçları Table 1: Chemical and microbiological analysis results of triticale varieties before ensiling

\begin{tabular}{|c|c|c|c|c|c|c|c|c|c|}
\hline & \multicolumn{3}{|c|}{ Karma 2000} & \multicolumn{3}{|l|}{ Presto } & \multicolumn{3}{|c|}{ Tatlıcak 97} \\
\hline & B & SO & HO & B & SO & HO & B & SO & HO \\
\hline pH & 6,05 & 6,12 & 6,33 & 6,14 & 6,23 & 6,30 & 6,10 & 6,20 & 6,41 \\
\hline $\mathbf{K M}$ & 31,79 & 37,14 & 40,40 & 31,54 & 34,27 & 38,30 & 33,70 & 36,61 & 42,03 \\
\hline SÇK, g/kg KM & 108,1 & 76,0 & 39,5 & 97,6 & 60,2 & 40,9 & 101,8 & 63,4 & 35,3 \\
\hline HK, \% КM & 7,26 & 6,56 & 5,74 & 7,55 & 6,62 & 5,72 & 7,89 & 6,69 & 6,51 \\
\hline HР, \% КМ & 11,23 & 10,32 & 10,06 & 12,42 & 10,01 & 9,85 & 12,52 & 10,20 & 9,45 \\
\hline NDF, \% KM & 66,21 & 60,17 & 57,20 & 67,77 & 61,92 & 56,42 & 65,91 & 61,94 & 58,19 \\
\hline $\mathrm{ADF}, \% \mathrm{KM}$ & 45,64 & 39,07 & 33,76 & 45,14 & 38,76 & 37,08 & 41,58 & 38,65 & 36,07 \\
\hline Lactobacilli, log kob/g KM & 2,26 & $<2,00$ & $<2,00$ & 2,80 & 2,50 & $<2,00$ & $<2,00$ & $<2,00$ & $<2,00$ \\
\hline
\end{tabular}

B:Başaklanma, SO: Süt olum, HO: Hamur olum, YOV: Yeşil ot verimi, KM: Kuru madde, SÇK: Suda çözünebilir karbonhidratlar, HK. Ham kül, HP: Ham protein, NDF: Nötr deterjanda çözünmeyen lif, ADF: Asit deterjanda çözünmeyen lif

Silolanmış tritikalenin kimyasal analiz sonuçları Tablo 2' de verilmiştir. Araştırmada Karma 2000 ve Presto çeşitlerine ait silajların $\mathrm{pH}$ değerleri başaklanma döneminde silajlarının her üç çeşitte de KM içeriği başaklanma döneminde önemli düzeyde düşük ( $\mathrm{P}<0.001)$; HK, HP, NDF, ADF ve SEL içerikleri ise aynı dönemde önemli düzeyde yüksek bulunmuştur $(\mathrm{P}<0.001)$. Karma 2000 ve Presto çeşitlerine ait silajların ADL içerikleri hamur olum döneminde önemli düzeyde düşük bulunurken $(\mathrm{P}<0.001)$, Tatlıcak 97 çeşidine ait silajlarda dönemler arası farklılıklar önemli bulunmamıştır $(\mathrm{P}>0.05)$. Hemiselüloz içeriklerinde ise Karma 2000 çeşidine ait silajlarda dönem farklılıkları önemsiz bulunurken $(\mathrm{P}>0.05)$; Presto çeşidinde süt olum döneminde, Tatlıcak 97 çeşidinde ise ise hamur olum döneminde önemli düzeyde yüksek olduğu saptanmıştır $(\mathrm{P}<0.001)$.

Silolanmış tritikalenin fermantasyon özelliklerine ait sonuçlar Tablo 3' de verilmiştir. Araştırmada Karma 2000 ve Presto çeşitlerine ait silajların pH değerleri başaklanma döneminde önemli düzeyde düşük bulunurken, Tatlıcak 97 çeşidinde ise dönemler arası farklılıklar önemsiz bulunmuştur. Her üç çeşit içinde başaklanma döneminde yapılan tritikale silajlarının LA içerikleri önemli düzeyde yüksek bulunmuştur $(\mathrm{P}<0.001)$. Başaklanma döneminde yapılan silajların AA içerikleri hamur olum dönemindeki silajlardan, $\mathrm{NH}_{3}-\mathrm{N}$ içerikleri ise süt ve hamur olum döneminde yapılan silajlardan önemli düzeyde düşük saptanmıştır $(\mathrm{P}<0.001)$. Tritikale silajlarında en yüksek lactobacilli sayısı hamur olum döneminde iken en yüksek maya sayısı ise başaklanma döneminde tespit edilmiştir $(\mathrm{P}<0.001)$. Tritikale silajlarının dönem farklılıkları BA içeriklerini etkilememiştir $(\mathrm{P}>0.05)$.

Farklı olgunlaşma dönemlerinde hasat edilen tritikale çeşitlerinin birim alandan elde edilen YOV, KMV, OMV, in vitro OMS, ME değerleri, SOMV ve MEV'e ilişkin değerler Tablo 4'de verilmiştir. Araştırmada Karma 2000 ve Presto çeşitlerine ait silajların YOV olgunlaşmanın ilerlemesi ile birlikte önemli düzeyde artarken $(\mathrm{P}<0.001)$, Tatlıcak 97 çeşidinde ise dönemler arası farklılıklar önemsiz bulunmuştur ( $\mathrm{P}>0.05)$. Her üç çeşit tritikale silajının KMV, OMV, SOMV ve MEV olgunlaşmanın ilerlemesiyle birlikte önemli düzeyde artış göstermiştir $(\mathrm{P}<0.001)$. Silajların en düşük OMS ve ME değerleri başaklanma döneminde tespit edilmiştir $(\mathrm{P}<0.001)$.

Silolamanın 75. gününde açılan tritikale silajlarına ait kimyasal analiz sonuçları Tablo 2' de verilmiştir. 
Tablo 2: Silolamanın 75. gününde açılan tritikale silajlarının kimyasal analiz sonuçları

Table 2: Chemical analysis of triticale silages opened on the 75th day of ensiling

\begin{tabular}{|c|c|c|c|c|c|c|c|c|c|}
\hline $\mathbf{C}$ & D & $\mathbf{K M}$ & HK & HP & NDF & ADF & ADL & HSEL & SEL \\
\hline \multirow[t]{3}{*}{$\mathrm{C} 1$} & B & $30,62 \pm 0,38 \mathrm{c}$ & $7,38 \pm 0,10 \mathrm{a}$ & $11,16 \pm 0,07 \mathrm{a}$ & $66,95 \pm 0,93 a$ & $44,61 \pm 0,60 \mathrm{a}$ & $5,87 \pm 0,29 \mathrm{a}$ & $22,34 \pm 0,61$ & $38,73 \pm 0,31 \mathrm{a}$ \\
\hline & SO & $34,37 \pm 0,21 b$ & $6,71 \pm 0,08 \mathrm{~b}$ & $9,90 \pm 0,10 \mathrm{~b}$ & $59,11 \pm 0,32 b$ & $38,12 \pm 0,55 b$ & $4,92 \pm 0,21 b$ & $20,99 \pm 0,50$ & $33,20 \pm 0,37 b$ \\
\hline & $\mathrm{HO}$ & $39,33 \pm 0,34 a$ & $5,83 \pm 0,28 \mathrm{c}$ & $9,97 \pm 0,52 b$ & $54,83 \pm 0,33 c$ & $33,06 \pm 0,41 \mathrm{c}$ & $4,02 \pm 0,13 \mathrm{c}$ & $21,78 \pm 0,11$ & $29,04 \pm 0,44 \mathrm{c}$ \\
\hline \multirow{2}{*}{$\mathrm{C} 2$} & SO & $32,62 \pm 0,17 \mathrm{~b}$ & $6,75 \pm 0,10 \mathrm{~b}$ & $9,88 \pm 0,06 \mathrm{~b}$ & $59,10 \pm 0,52 b$ & $37,57 \pm 0,68 b$ & $5,34 \pm 0,20 \mathrm{~b}$ & $21,53 \pm 0,19 a$ & $32,23 \pm 0,55 b$ \\
\hline & $\mathrm{HO}$ & $37,65 \pm 0,07 \mathrm{a}$ & $5,77 \pm 0,05 \mathrm{c}$ & $9,75 \pm 0,07 \mathrm{~b}$ & $54,26 \pm 0,55 c$ & $35,27 \pm 1,04 \mathrm{c}$ & $3,96 \pm 0,23 \mathrm{c}$ & $18,99 \pm 1,45 b$ & $31,31 \pm 0,82 b$ \\
\hline $\mathrm{C} 3$ & $\mathrm{HO}$ & $40,60 \pm 0,26 \mathrm{a}$ & $6,70 \pm 0,10 \mathrm{~b}$ & $9,30 \pm 0,14 \mathrm{c}$ & $56,86 \pm 0,43 c$ & $35,42 \pm 0,38 \mathrm{c}$ & $4,27 \pm 0,13$ & $21,44 \pm 0,24 b$ & $31,15 \pm 0,30 \mathrm{c}$ \\
\hline D & $\mathbf{C}$ & & & & & & & & \\
\hline \multirow[t]{3}{*}{ B } & $\mathrm{C} 1$ & $30,62 \pm 0,38 b$ & $7,38 \pm 0,10 \mathrm{~b}$ & $11,16 \pm 0,07 b$ & $66,95 \pm 0,93$ & $44,61 \pm 0,60 \mathrm{a}$ & $5,87 \pm 0,29 a$ & $22,34 \pm 0,61 b$ & $38,73 \pm 0,31 \mathrm{a}$ \\
\hline & $\mathrm{C} 2$ & $29,53 \pm 0,15 \mathrm{c}$ & $7,71 \pm 0,10 \mathrm{ab}$ & $12,15 \pm 0,11 \mathrm{a}$ & $65,24 \pm 0,84$ & $44,02 \pm 0,65 \mathrm{a}$ & $6,53 \pm 0,37 \mathrm{a}$ & $21,22 \pm 0,81 b$ & $37,49 \pm 0,32 \mathrm{a}$ \\
\hline & $\mathrm{C} 3$ & $32,26 \pm 0,39 a$ & $7,95 \pm 0,05 \mathrm{a}$ & $12,64 \pm 0,52 \mathrm{a}$ & $65,35 \pm 0,41$ & $40,03 \pm 0,89 b$ & $4,44 \pm 0,38 b$ & $25,32 \pm 0,81 \mathrm{a}$ & $35,59 \pm 0,57 b$ \\
\hline \multirow{2}{*}{$\mathrm{HO}$} & $\mathrm{C} 2$ & $37,65 \pm 0,07 \mathrm{c}$ & $5,77 \pm 0,05 b$ & $9,75 \pm 0,07$ & $54,26 \pm 0,55 b$ & $35,27 \pm 1,04 \mathrm{a}$ & $3,96 \pm 0,23$ & $18,99 \pm 1,45 b$ & $31,31 \pm 0,82 \mathrm{a}$ \\
\hline & $\mathrm{C} 3$ & $40,60 \pm 0,26 \mathrm{a}$ & $6,70 \pm 0,10 \mathrm{a}$ & $9,30 \pm 0,14$ & $56,86 \pm 0,43 \mathrm{a}$ & $35,42 \pm 0,38 \mathrm{a}$ & $4,27 \pm 0,13$ & $21,44 \pm 0,24 \mathrm{a}$ & $31,15 \pm 0,30 \mathrm{a}$ \\
\hline D & & $<0,001$ & $<0,001$ & $<0,001$ & $<0,001$ & $<0,001$ & $<0,001$ & 0,007 & $<0,001$ \\
\hline $\mathbf{C}$ & & $<0,001$ & $<0,001$ & 0,325 & 0,173 & 0,124 & 0,001 & 0,011 & 0,796 \\
\hline Ç*D & & 0,707 & 0,005 & $<0,001$ & 0,114 & 0,001 & 0,002 & 0,061 & $<0,001$ \\
\hline
\end{tabular}

Ç: Çeşit, D: Olgunlaşma Dönemi, C1: Karma 2000, C2: Presto, C3: Tatllcak 97, B:Başaklanma, SO: Süt olum, HO: Hamur olum, KM: kuru madde, HP: Ham protein,

NDF: Nötr deterjanda çözünmeyen lif, ADF: Asit deterjanda çözünmeyen lif, ADL, asit deterjanda çözünmeyen lignin, HSEL: Hemiselüloz, SEL: Selüloz. 
Tablo 3: Silolamanın 75. gününde açılan tritikale silajlarının fermantasyon özellikleri

Table 3: Fermentation properties of triticale silages opened on the 75th day of ensiling

\begin{tabular}{|c|c|c|c|c|c|c|c|c|}
\hline Ç & D & pH & $\mathbf{L A}$ & $\mathbf{A A}$ & $\mathbf{B A}$ & $\mathrm{NH}_{3}-\mathrm{N}$ & Lactobacilli & Maya \\
\hline \multirow[t]{3}{*}{$\mathrm{C} 1$} & B & $3,99 \pm 0,05 b$ & $57,95 \pm 1,66 a$ & $7,44 \pm 0,21 b$ & $1,42 \pm 0,72$ & $48,85 \pm 1,29 b$ & $4,76 \pm 0,10 \mathrm{c}$ & $2,74 \pm 0,21 a$ \\
\hline & SO & $4,24 \pm 0,04 \mathrm{a}$ & $48,07 \pm 1,57 b$ & $8,62 \pm 0,36 \mathrm{ab}$ & $0,78 \pm 0,78$ & $55,56 \pm 2,42 \mathrm{a}$ & $5,14 \pm 0,03 b$ & $1,81 \pm 0,24 b$ \\
\hline & $\mathrm{HO}$ & $4,33 \pm 0,05 \mathrm{a}$ & $41,37 \pm 1,33 c$ & $9,26 \pm 0,41 \mathrm{a}$ & $1,21 \pm 0,41$ & $56,42 \pm 2,05 \mathrm{a}$ & $5,51 \pm 0,10 \mathrm{a}$ & $2,17 \pm 0,05 b$ \\
\hline \multirow[t]{3}{*}{$\mathrm{C} 2$} & $\mathrm{~B}$ & $4,04 \pm 0,02 b$ & $58,14 \pm 1,66 a$ & $9,70 \pm 0,42 b$ & $0,78 \pm 0,68$ & $48,03 \pm 0,66 b$ & $4,98 \pm 0,06 \mathrm{~b}$ & $3,05 \pm 0,21 \mathrm{a}$ \\
\hline & SO & $4,23 \pm 0,04 \mathrm{a}$ & $44,61 \pm 2,21 b$ & $14,48 \pm 0,98 a$ & $1,67 \pm 0,77$ & $58,11 \pm 1,86 a$ & $5,15 \pm 0,08 b$ & $2,84 \pm 0,09 a$ \\
\hline & $\mathrm{HO}$ & $4,27 \pm 0,06 \mathrm{a}$ & $37,20 \pm 1,01 \mathrm{c}$ & $15,14 \pm 0,77 \mathrm{a}$ & $1,74 \pm 0,75$ & $58,54 \pm 1,37 \mathrm{a}$ & $5,71 \pm 0,08 \mathrm{a}$ & $2,14 \pm 0,21 b$ \\
\hline \multirow[t]{3}{*}{ C3 } & $\mathrm{B}$ & $4,02 \pm 0,03$ & $56,81 \pm 1,25 \mathrm{a}$ & $8,82 \pm 0,76 b$ & $0,51 \pm 0,38$ & $46,66 \pm 3,38 b$ & $5,13 \pm 0,04 b$ & $2,95 \pm 0,24 a$ \\
\hline & $\mathrm{SO}$ & $4,17 \pm 0,02$ & $48,79 \pm 1,25 b$ & $9,79 \pm 0,43 \mathrm{ab}$ & $1,55 \pm 0,41$ & $54,96 \pm 1,44 a$ & $5,20 \pm 0,03 \mathrm{ab}$ & $1,87 \pm 0,08 b$ \\
\hline & $\mathrm{HO}$ & $4,21 \pm 0,04$ & $35,59 \pm 0,98 \mathrm{c}$ & $11,03 \pm 0,45 a$ & $0,78 \pm 0,01$ & $55,73 \pm 1,24 a$ & $5,37 \pm 0,05 a$ & $1,91 \pm 0,11 b$ \\
\hline D & Ç & & & & & & & \\
\hline \multirow[t]{3}{*}{ B } & $\mathrm{C} 1$ & $3,99 \pm 0,05$ & $57,95 \pm 1,66$ & $7,44 \pm 0,21 b$ & $1,42 \pm 0,72$ & $48,85 \pm 1,29$ & $4,76 \pm 0,10 b$ & $2,74 \pm 0,21$ \\
\hline & $\mathrm{C} 2$ & $4,04 \pm 0,02$ & $58,14 \pm 1,66$ & $9,70 \pm 0,42 \mathrm{a}$ & $0,78 \pm 0,68$ & $48,03 \pm 0,66$ & $4,98 \pm 0,06 \mathrm{a}$ & $3,05 \pm 0,21$ \\
\hline & $\mathrm{C} 3$ & $4,02 \pm 0,03$ & $56,81 \pm 1,25$ & $8,82 \pm 0,76 \mathrm{ab}$ & $0,51 \pm 0,38$ & $46,66 \pm 3,38$ & $5,13 \pm 0,04 \mathrm{a}$ & $2,94 \pm 0,24$ \\
\hline \multirow[t]{3}{*}{ SO } & $\mathrm{C} 1$ & $4,24 \pm 0,04$ & $48,07 \pm 1,57$ & $8,62 \pm 0,36 b$ & $0,78 \pm 0,78$ & $55,56 \pm 2,42$ & $5,14 \pm 0,03$ & $1,81 \pm 0,24 b$ \\
\hline & $\mathrm{C} 2$ & $4,23 \pm 0,04$ & $44,61 \pm 2,21$ & $14,48 \pm 0,98 a$ & $1,67 \pm 0,77$ & $58,11 \pm 1,86$ & $5,15 \pm 0,08$ & $2,84 \pm 0,09 a$ \\
\hline & $\mathrm{C} 3$ & $4,17 \pm 0,02$ & $48,79 \pm 1,25$ & $9,79 \pm 0,43 b$ & $1,55 \pm 0,41$ & $54,96 \pm 1,44$ & $5,20 \pm 0,03$ & $1,87 \pm 0,08 b$ \\
\hline \multirow[t]{3}{*}{$\mathrm{HO}$} & $\mathrm{C} 1$ & $4,33 \pm 0,05 \mathrm{a}$ & $41,37 \pm 1,33 a$ & $9,26 \pm 0,41 c$ & $1,21 \pm 0,41$ & $56,42 \pm 2,05$ & $5,51 \pm 0,10 b$ & $2,17 \pm 0,05$ \\
\hline & $\mathrm{C} 2$ & $4,27 \pm 0,06 \mathrm{ab}$ & $37,20 \pm 1,01 \mathrm{ab}$ & $15,14 \pm 0,77 \mathrm{a}$ & $1,74 \pm 0,75$ & $58,54 \pm 1,37$ & $5,71 \pm 0,08 \mathrm{a}$ & $2,13 \pm 0,21$ \\
\hline & $\mathrm{C} 3$ & $4,21 \pm 0,04 b$ & $35,59 \pm 0,98 b$ & $11,03 \pm 0,45 b$ & $0,78 \pm 0,01$ & $55,73 \pm 1,24$ & $5,37 \pm 0,05 \mathrm{ab}$ & $1,91 \pm 0,11$ \\
\hline D & & $<0,001$ & $<0,001$ & $<0,001$ & 0,661 & $<0,001$ & $<0,001$ & $<0,001$ \\
\hline Ç & & 0,219 & 0,119 & $<0,001$ & 0,663 & 0,313 & 0,056 & 0,009 \\
\hline Ç*D & & 0,385 & 0,128 & 0,013 & 0,587 & 0,916 & 0,006 & 0,043 \\
\hline
\end{tabular}

Ç: Çeşit, D: Olgunlaşma Dönemi, C1: Karma 2000, C2: Presto, C3: Tatlıcak 97, B:Başaklanma, SO: Süt olum, HO: Hamur olum, NH3-N: Amonyak azotu;

TN: Toplam nitrojen LA: Laktik asit, AA: Asetik asit, BA: Bütirik asit 
Tablo 4: Tritikale silajlarına ait yeşil ot, kuru madde, organik madde, in vitro organik madde sindirimi, metabolik enerji değerleri, sindirilebilir organik madde ve metabolik enerji verimi

Table 4: Green grass, dry matter, organic material, in vitro organic matter digestion, metabolic energy values, digestible organic matter and metabolic energy yield of triticale silages

\begin{tabular}{|c|c|c|c|c|c|c|c|c|}
\hline $\mathbf{C}$ & D & YOV,kg/da & KMV,kg/da & OMV,kg/da & OMS, \% & SOMV,kg/da & ME,MJ/kg KM & MEV,MJ/da \\
\hline \multirow[t]{2}{*}{$\mathrm{C} 1$} & $\mathrm{~B}$ & $3,020 \pm 60 \mathrm{c}$ & $934 \pm 12 c$ & $866 \pm 12 c$ & $46,49 \pm 0,62 c$ & $403 \pm 11 c$ & $7,02 \pm 0,08 \mathrm{c}$ & $6,568 \pm 163 c$ \\
\hline & $\mathrm{HO}$ & $4,155 \pm 103 a$ & $1,651 \pm 33 a$ & $1,556 \pm 28 \mathrm{a}$ & $56,10 \pm 0,09 \mathrm{a}$ & $873 \pm 14 a$ & $8,38 \pm 0,05 a$ & $13,834 \pm 196 \mathrm{a}$ \\
\hline \multirow{2}{*}{$\mathrm{C} 2$} & SO & $3,856 \pm 63 b$ & $1,277 \pm 29 b$ & $1,192 \pm 27 b$ & $55,76 \pm 1,04 \mathrm{a}$ & $665 \pm 20 b$ & $8,20 \pm 0,11 \mathrm{a}$ & $10,470 \pm 287 b$ \\
\hline & $\mathrm{HO}$ & $4,337 \pm 127 \mathrm{a}$ & $1,640 \pm 52 \mathrm{a}$ & $1,546 \pm 49 \mathrm{a}$ & $55,08 \pm 0,26 \mathrm{a}$ & $852 \pm 30 \mathrm{a}$ & $8,26 \pm 0,04 a$ & $13,544 \pm 465 \mathrm{a}$ \\
\hline \multirow[t]{2}{*}{$\mathrm{C} 3$} & B & $4,662 \pm 129$ & $1,507 \pm 41 \mathrm{c}$ & $1,389 \pm 37 \mathrm{c}$ & $50,52 \pm 0,25 b$ & $702 \pm 22 c$ & $7,46 \pm 0,03 b$ & $11,248 \pm 355 \mathrm{c}$ \\
\hline & $\mathrm{HO}$ & $4,694 \pm 99$ & $1,950 \pm 31 \mathrm{a}$ & $1,823 \pm 27 \mathrm{a}$ & $53,87 \pm 0,41 \mathrm{a}$ & $982 \pm 21 \mathrm{a}$ & $7,97 \pm 0,04 \mathrm{a}$ & $15,535 \pm 305 \mathrm{a}$ \\
\hline D & Ç & & & & & & & \\
\hline \multirow[t]{3}{*}{ B } & $\mathrm{C} 1$ & $3,020 \pm 60 \mathrm{c}$ & $934 \pm 12 c$ & $866 \pm 12 c$ & $46,49 \pm 0,62 b$ & $403 \pm 11 c$ & $7,02 \pm 0,08 b$ & $6,568 \pm 163 c$ \\
\hline & $\mathrm{C} 2$ & $3,809 \pm 87 b$ & $1,143 \pm 33 b$ & $1,056 \pm 30 \mathrm{~b}$ & $47,64 \pm 0,69 b$ & $503 \pm 17 b$ & $7,14 \pm 0,10 b$ & $8,155 \pm 267 b$ \\
\hline & $\mathrm{C} 3$ & $4,662 \pm 129 a$ & $1,507 \pm 41 \mathrm{a}$ & $1,389 \pm 37 \mathrm{a}$ & $50,52 \pm 0,25 \mathrm{a}$ & $702 \pm 22 \mathrm{a}$ & $7,46 \pm 0,03 a$ & $11,248 \pm 355 \mathrm{a}$ \\
\hline SO & $\mathrm{C} 1$ & $3,515 \pm 74 \mathrm{c}$ & $1,230 \pm 30 b$ & $1,150 \pm 27 b$ & $52,82 \pm 0,73 b$ & $608 \pm 22 b$ & $7,85 \pm 0,07 b$ & $9,670 \pm 320 b$ \\
\hline \multirow{2}{*}{$\mathrm{HO}$} & $\mathrm{C} 2$ & $4,337 \pm 127 \mathrm{a}$ & $1,640 \pm 52 b$ & $1,546 \pm 49 b$ & $55,08 \pm 0,26 a b$ & $852 \pm 30 b$ & $8,26 \pm 0,04 a$ & $13,544 \pm 465 b$ \\
\hline & $\mathrm{C} 3$ & $4,694 \pm 99 a$ & $1,950 \pm 31 \mathrm{a}$ & $1,823 \pm 27 \mathrm{a}$ & $53,87 \pm 0,41 b$ & $982 \pm 21 \mathrm{a}$ & $7,97 \pm 0,04 b$ & $15,535 \pm 305 \mathrm{a}$ \\
\hline D & & $<0,001$ & $<0,001$ & $<0,001$ & $<0,001$ & $<0,001$ & $<0,001$ & $<0,001$ \\
\hline Ç & & $<0,001$ & $<0,001$ & $<0,001$ & 0,120 & $<0,001$ & 0,083 & $<0,001$ \\
\hline Ç*D & & $<0,001$ & 0,006 & 0,004 & $<0,001$ & 0,003 & $<0,001$ & 0,002 \\
\hline
\end{tabular}

Ç: Çeşit, D: Olgunlaşma Dönemi, C1: Karma 2000, C2: Presto, C3: Tatlicak 97, B:Başaklanma, SO: Süt olum, HO: Hamur olum, YOV: Yeşil ot verimi, KMV: Kuru madde verimi, OMV: Organik madde verimi, OMS: Organik madde sindirimi, ME: Metabolik enerji, SOMV. Sindirilebilir organik madde verimi, MEV: Metabolik enerji verimi 


\section{Tartışma ve Sonuç}

Hasat zaman1, tritikale çeşitlerinin kimyasal kompozisyonunu önemli derecede etkilemiştir. Araştırmada olgunlaşma döneminin ilerlemesi ile tritikale çeşitlerinin kuru madde (KM) ve pH değerlerinin yükseldiği; SÇK, HK, HP, NDF ve ADF içeriklerinin azaldığı görülmüştür (Tablo 1). Hasat zamanına bağlı olarak kimyasal kompozisyonda meydana gelen değişimler Filya (13), Geren (17), Keleş (23) ile Sucu ve Aydoğan Çiftçi (37) bulgularıyla uyum içerisindedir. Hasat döneminde yeşil materyalde yer alan epifitik lactobacilli sayısındaki değişimler sıcaklık, nispi nem, ultraviyole radyasyon ve bitki ile ilgili özellikler olmak üzere birçok faktörün etkisi altındadır. McDonald ve ark. (28) söz konusu değişimlerin 1.0-6.0 log kob/g sınırları arasında gerçekleşebileceğini bildirilmektedirler. Araştırmada farklı olgunlaşma dönemlerinde hasat edilen tritikale çeşitlerinin epifitik lactobacilli sayılarının her bir grupta $<3.00 \log \mathrm{kob} / \mathrm{g}$ ile oldukça düşük düzeyde olduğu saptanmıştır (Tablo 1).

Farklı olgunluk dönemlerinde hasat edilen bazı tritikale çeşitlerinden elde edilen silajların KM içerikleri \%29.53-40.60 arasında olup, hasat dönemin ilerlemesi ile birlikte her üç çeşidinde KM miktarları önemli düzeyde artmıştır $(\mathrm{P}<0.001)$ (Tablo 2). Çalışmada incelenen tritikale çeşitlerde her üç olgunluk döneminde de Tatlıcak 97 çeşitinin KM miktarları diğer çeşitlerden önemli düzeyde daha yüksek bulunmuştur $(\mathrm{P}<0.05)$. Silolamanın 75 . gününde açılan tritikale silajların HK içerikleri \%5,77-7,95 arasında değişmekte olup gruplar arasındaki farklılıklar önemli bulunmuştur $(\mathrm{P}<0.001)$. Başaklanma döneminde HK içeriklerinin önemli düzeyde yüksek olduğu tespit edilirken, başaklanma ve hamur olum dönemlerinde en yüksek HK içerikleri Tatlıcak 97 silajlarında belirlenmiştir $(\mathrm{P}<0.001)$. Tritikale silajlarının KM'de HP içerikleri olgunlaşma döneminin ilerlemesi ile önemli düzeyde azalma tespit edilirken $(\mathrm{P}<0.001)$, çeşitler arasındaki farklılık da ise sadece başaklanma döneminde Karma 2000 çeşidinde HP içeriği diğer çeşitlere göre önemli düzeyde daha düşük bulunmuştur ( $\mathrm{P}>0.05$ ) (Tablo 2). Nadeau (29), süt olum döneminde hasat edilen tritikale silajlarının \%29.20 KM ve \%10,31 HP; hamur olum döneminde ise $\% 35.00 \mathrm{KM}$ ve \%7.70 HP içerdiğini bildirmektedir. Kaplan ve ark. (21), hamur olum döneminde hasat edilerek silolanan 10 farklı tritikale çeşidinde KM, HP ve HK içeriklerini sırasıyla \%35.54-41.60, \%7.34-10.25 ve \%5.21-7.19 arasında değiştiğini saptamışlardır. Sucu ve Akdoğan Çifci (37)'nın hamur olum döneminde hasat edilerek silolanan dört farklı tritikale çeşidinde KM, HP ve HK, içeriklerini sırasıyla \%37.37-38.38, \%8.92-9.14, \%7.41-7.55 arasında olduğunu bildirmektedirler. Hasat zamanının ilerlemesiyle birlikte tritikale silajlarının HP içeriğindeki düşüş bitkide bulunan yaprak ve sap kısımlarındaki HP'nin azalmasından kaynaklanmaktadır. Tüm çeşitlerde en yüksek HP içerikleri başaklanma dönemlerinde elde edilirken, olgunlaşma dönemi ilerledikçe yaşlanmanın doğal sonucu olarak HP içeriklerinde azalma meydana gelmiştir. Buxton (8) bitkinin olgunlaşmasıyla birlikte HP bakımdan oldukça fakir olan sap kısmının arttığını bildirmektedir. Collar ve Aksland (11), bitki olgunluğunun artmasıyla tohumda nişastanın birikmesi sonucu ADF ve NDF'nin azalmasına neden olabileceğini bildirmektedirler. Nitekim tritikale silajlarının tümünde KM'de NDF ve ADF içerikleri olgunlaşma döneminin ilerlemesi ile önemli düzeyde azalmıştır $(\mathrm{P}<0.001)$ (Tablo 2). Silajların en düşük ADL ve SEL içerikleri hamur olum döneminde saptanmış olup $(\mathrm{P}<0.01)$, ADL içerikleri bakımından Tatlıcak 97 çeşidinde dönemler arasındaki farklılıklar önemsiz bulunmuştur ( $\mathrm{P}>0.05)$. Tritikale silajlarının HSEL içerikleri bakımından Karma 2000 grubunda olgunluk döneminin etkisi önemsiz bulunurken, Presto ve Tatlıcak 97 grubunda en düşük HSEL içeriği hamur olum döneminde tespit edilmiştir ( $\mathrm{P}=0.007)$. Kaplan ve ark. (21), hamur olum döneminde hasat edilerek silolanan 10 farklı tritikale çeşidinde NDF ve ADF içeriklerini sırasıyla \%51.24-60.00, \%33.93-39.47 arasında değiştiğini saptamışlardır. Sucu ve Akdoğan Çifci (37)'nın hamur olum döneminde hasat edilerek silolanan dört farklı tritikale çeşidinde NDF, ADF ve HSEL içeriklerini sırasıyla \%56.41-56.97, \%35.49-36.36 ve \%20.05-21.65 arasında olduğunu bildirmektedirler. Wallsten (40), süt olum döneminde silolanan tritikalerin nişasta ve NDF içeriklerini sırasılyla \%2.6 ve \%48.9; hamur olum dönemlerinde ise aynı sırayla \%20.2 ve \% 44.6 olarak tespit etmiştir. Araştırmacı olgunlaşmanın ilerlemesiyle artan nişasta içeriğinin NDF miktarını azaldığını bildirmektedir. Filya (13) ve Nair ve ark. (30) olgunluk döneminin ilerlemesiyle buğdaygil silajlarında NDF ve ADF içeriklerinin azaldığını belirtmektedir.

Silajların niteliğinin belirlenmesinde önemli kriterlerden biri, silajların $\mathrm{pH}$ düzeyleridir. Bu çalışmada tritikale silajların pH düzeyleri 3,99-4,33 arasında bulunmuştur. Karma 2000 ve Presto çeşitlerinde silajların pH değerleri başaklanma döneminde önemli düzeyde azaldığı belirlenmiştir $(\mathrm{P}<0.001)$. Tatlıcak 97 çeşitinde en düşük pH değeri başaklanma döneminde tespit edilmiş olup, bu çeşitte olgunlaşma dönemleri arasındaki farklılıkların istatistiki anlamda önem taşımadığı görülmüştür ( $\mathrm{P}>0.05)$. Silajların pH değerleri, silajlar için istenilen optimum 3.8-4.2 değerlerine (27) 
oldukça yakın bulunmuştur. Tritikale silajlarının LA içerikleri 35,59-58,14 g/kg KM arasında değişmiş olup, her üç çeşidin de LA içerikleri olgunlaşma döneminin ilerlemesiyle birlikte önemli düzeyde azalmıştır $(\mathrm{P}<0.001)$. $\mathrm{Bu}$ çalışmada başaklanma döneminde hasat edilen tritikalenin yüksek düzeyde SÇK içeriğine sahip olması bu dönemde yapılan silajların daha düşük pH değeri ve daha yüksek LA miktarı üzerine etkili olmuştur. Özellikle LAB'i SÇK'ları kullanarak LA üretimini artırmış ve asidik bir ortam oluşturması ile pH'yı düşürmüştür. Asetik asit içeriğindeki artış silajın KM ve enerji kayıplarını yükseltir. Tüm çeşitler ve olgunlaşma dönemlerinde AA içerikleri silajlar için kabul edilen 5-30 g/kg KM arasında bulunmuştur (25; 31). Kaliteli bir silajda istenmemekle birlikte 1.0-7.0 g/kg arasında BA içeriğine rastlanmaktadır (3). Nitekim bu çalışma da BA içeriği 0.51-1.74 g/kg KM arasında saptanmış ve gerek çeşit gerekse de dönemler arasındaki farklılıklar önemsiz bulunmuştur ( $\mathrm{P}>0.05)$. Silajdaki gerçek proteinler, bitki hücre duvarının parçalanıp bitki enzimlerinin (özellikle proteazlar) serbest hale geçmesinden sonraki aktiviteleri sonucu parçalanırlar. Düşük pH, yüksek KM içeriği ve düşük sıcaklıklar, silolanan bitki bünyesindeki enzim aktivitesini azaltarak protein parçalanabilirliğini düşürürler (14). Tritikale silajlarının NH3-N içerikleri toplam nitrojen (TN)' de 46,66-58,54 g/kg arasında değişmiştir. Tritikale silajlarının NH3-N düzeyleri bakımından çeşitler arasında önemli farklılıklar bulunmazken ( $\mathrm{P}>0.05$ ), başaklanma dönemindeki tritikale silajlarının NH3-N içerikleri süt ve hamur olum dönemindeki silajlardan önemli düzeyde daha düşük bulunmuştur $(\mathrm{P}<0.001)$. McDonald ve ark. (28), kaliteli bir silaj için NH3-N miktarının $100 \mathrm{~g} / \mathrm{kg}$ TN düzeyinin üzerine çıkmaması gerektiği bildirmektedirler. Bu çalışmada, silajların tümünün NH3-N miktarları bakımından iyi kalitede olduğunu tespit edilmiştir. Silajların lactobacilli sayıları 4,76-5,71 $\log \mathrm{kob} / \mathrm{g}$ ve maya sayıları 1,81-3,05 log kob/g arasında olup, tüm çeşitlerde en yüksek lactobacilli sayısı hamur olum döneminde saptanırken $(\mathrm{P}<0.01)$, en yüksek maya sayısı ise başaklanma döneminde tespit edilmiştir $(\mathrm{P}<0.001)$. $\mathrm{Bu}$ bulgular Ozduven ve ark. (32) ile Sucu ve Aydoğan Çifci (37)'nin elde etitiği bulgular ile uyum içerisindedir.

Olgunlaşmanın ilerlemesi ile bitkiler de yapısal maddeler artmakta ve yeni dokular meydana gelmektedir. Bunun sonucu olarak da YOV ve KMV'de (biomas) artış olmaktadır (39). Tritikale silajlarının YOV 3020-4815 kg/da arasında olup, Karma 2000 ve Presto çeşitinde YOV hamur olum döneminde önemli düzeyde daha yüksek tespit edilmiştir $(\mathrm{P}<0.001)$. Tatlıcak 97 çeşidinde ise YOV yine hamur olum döneminde daha yüksek saptanmış ancak dönemler arasındaki farklılıklar önemsiz bulunmuştur $(\mathrm{P}>0.05)$. Çeşitler arasındaki farklılıklar incelendiğinde ise en düşük YOV her üç olgunluk dönemi içinde Karma 2000 silajında tespit edilmiştir. Tritikale silajlarının KMV ve OMV sırasıyla 934-1950 kg/da ve 866-1823 kg/da arasında değişmiş olup en yüksek değerler hamur olum döneminde, en düşük değerler ise başaklanma döneminde elde edilmiştir $(\mathrm{P}<0.001)$. Ayrıca tritikale ç̧eşitleri arasındaki farklılıklarda istatistiksel anlamda önemli olup, her üç dönem içinde en yüksek KMV ve OMV Tatlıcak 97 çeşidinde saptanmıştır $(\mathrm{P}<0.001)$. Sucu ve Aydoğan Çifci (37)'nın Bursa ili koşullarında yürüttükleri ve araştırma materyali olarak dört tritikale çeşidini kullandıkları çalışmalarında, hamur olum döneminde hasat edilen çeşitlerinin YOV ve KMV sırasıyla 4161-4428 kg/da ve 1386-1594 kg/da arasında değiştiğini bildirmektedirler. Geren (17)'nın İzmir ili koşullarında 2010 ve 2011 yıllarında yürüttükleri ve farklı dönemlerde hasat ettikleri tritikalenin iki yıllık KMV ortalaması başaklanma, süt olum ve hamur olum dönemleri için sırasıyla 770, 947 ve $1311 \mathrm{~kg} /$ da olarak tespit etmişlerdir. Yeşil ot verimi ve KMV gibi verim parametreleri tohum miktarına, gübrelemeye, iklim ve toprak özelliklerine, yağış miktarına, sulamaya, ekim sıklığına ve olgunlaşma dönemine bağlı olarak birçok faktörden etkilenebilmektedir (1). Çalışmamızdaki tritikale çeşitlerinin Geren (17) ile Sucu ve Aydoğan Çifci (37) bildirdiği YOV ve KMV'nden daha yüksek olarak gerçekleşmiş olması belirtilen faktörlerin etkilerinden kaynaklanabilir. Tritikale silajlarının in vitro OMS dereceleri \%46,49-56,10, birim alandan elde edilen SOMV 403-982 kg/da, ME değerleri 7,02-8,38 MJ/kg KM ve MEV 6,568-15,535 MJ/da arasında bulunmuştur. Yapılan birçok çalışmada OMS ve ME değeri ile NDF, ADF ve ADL gibi hücre duvarını oluşturan unsurlar arasında negatif bir ilişki olduğu bildirilmektedir (9;22). Süt ve hamur olum dönemlerinde tritikale silajlarının nişasta içeriğinin artması ve hücre duvarı bileşenlerindeki azalmaya paralel olarak OMS ve ME değerleri başaklanma dönemindeki silajlara göre önemli düzeyde artmıştır $(\mathrm{P}<0.001)$. Çeşitler arasındaki farklılıklar incelendiğinde ise tritikale silajlarının ME değeri başaklanma döneminde Tatlıcak 97'de, süt olum döneminde Presto'da ve hamur olum döneminde ise Karma 2000 ve Presto çeşidinde önemli düzeyde yüksek bulunmuştur $(\mathrm{P}<0.001)$. Her üç tritikale çeşidinde de olgunlaşmanın ilerlemesi ile birlikte KMV ve OMV artmasılyla birim alandan elde edilen SOMV ve MEV önemli düzeylerde artış göstermiştir $(\mathrm{P}<0.001)$. En yüksek SOMV ve MEV değerleri hamur olum dönemlerinde olup, tüm dönemlerde en yüksek değerler Tatlıcak 97 çeşidinde saptanmıştır. Özdüven ve ark. (32), süt olum döneminde hasat edilen ve silolamanın 45. günde açılan tiritikale silajının KMS ve OMS'ni sırasıyla \%57,60 ve 
\%60.10; Sucu ve Akdoğan Çifci (37), hamur olum döneminde hasat edilen dört farklı tritikale çeşidinin KMS ve OMS'ni sırasıyla \%48,39-48,95 ve \%49,67-50.36 arasında tespit etmişlerdir. Bu çalışmada OMS ve ME değerleri, Canbolat (9)'ın geç süt olum döneminde hasat edilen tritikale hasıllarının OMS ve ME değerlerini sırasıyla \%69.2 ve $9.9 \mathrm{MJ} / \mathrm{kg} \mathrm{KM}$ olarak bildirdiği değerlerden daha düşük bulunmuştur.

Araştırma sonuçlarına göre; olgunlaşma dönemi tritikale silajlarının fermantasyon özellikleri, YOV, KMV ve OMV ile yem değerini önemli düzeyde etkilemiştir. Olgunlaşmanın ilerlemesiyle verim artmasına rağmen, fermantasyon özelliklerinde azalma olmuştur. Tritikale silajlarının verim kriterleri göz önüne alındığında, en uygun hasat döneminin hamur olum döneminde olduğu, Tekirdağ ili koşullarında üretilen tritikale çeşitlerinden Tatlıcak97’nin ise diğer tritikale çeşitlerinden elde edilen silajlara göre daha iyi sonuçlar verdiği tespit edilmiştir.

\section{Kaynaklar}

1. Açıkgöz E (1991): Yem Bitkileri. Uludağ Üniversitesi Yayınları No:633-2, s.456, Bursa.

2. Albayrak S, Mut Z, Töngel Ö (2006): Tritikale (X Triticosecale Wittmack) hatlarında kuru ot ve tohum verimi ile bazı tarımsal özellikler. SDÜ Ziraat Fakültesi Dergisi, 1(1): 13-21.

3. Alçiçek A, Özkan K (1997): Silo yemlerinde fiziksel ve kimyasal yöntemlerle silaj kalitesinin saptanması, Türkiye I. Silaj Kongresi, 235-240, Bursa.

4. Anonymus (1986): The Analysis of Agricultural Material, Reference Book:427, London, 428 p.

5. Anonymus (1998): Ausschuss für Bedarfsnormen der Gesellschaft für Ernährungsphysiologie. Proc Soc Nutr Physiol, 7, 141-149.

6. Aufrère J, Michalet-Doreau B (1988): Comparison of methods for predicting digestibility of feeds. Anim. Feed Sci. Technol, 20, 203-218.

7. Barier AC, Dias JA, Nedel JL (1980): Triticale research. Annual Wheat Newsletter, 26, 46-47.

8. Buxton DR (1996): Quality related characteristics of forages as influenced by plant environment and agronomic factors. Anim Feed Sci Technol, 59(1-3), 37-49.

9. Canbolat $\mathbf{O}$ (2012): Comparison of in vitro gas production, organic matter digestibility, relative feed value and metabolizable energy contents of some cereal forages. Kafkas Univ Vet Fak Derg 18 (4), 571-577.

10. Chen J, Stokes MR, Wallace CR (1994): Effects of enzyme-inoculant systems on preservation and nutritive value of hay crop and corn silages. J. Dairy Sci, 77, 501-512.

11. Collar C, Aksland G (2001): Harvest stage effects on yield and quality of winter forage. Erişim adresi: http://alfalfa.ucdavis.edu/+symposium/proceedings/2001/01-133.pdf Erişim tarihi:15.12. 2018.

12. Delogu G, Faccini N, Faccioli P, Reggiani F, Lendini M, Berardo N, Odoardi M (2002): Dry matter yield and quality evaluation at two phenological stages of forage triticale grown in the Po Valley and Sardinia, Italy. Field Crops Res, 74, 207-215.

13. Filya I (2003): Nutritive value ofwhole crop wheat silage harvested at three stages of maturity. Anim Feed Sci Technol, 103, 85-95.

14. Filya İ (2005): Silaj Yapımı, Teknolojisi ve Kullanımı. Süt Hayvancılığı Eğitim Merkezi Yayınları, Hayvancılık Serisi : 8 Yetiştirici El Kitabı, Karacabey, Bursa

15. Fischer RA (1993): Cereal breeding in developing countries: progress and prospects. In: International Crop Science I Crop Se. Society of America, Inc. Madison, Wisconsin, 201-209.

16. Genç İ, Ülger AC, Yağbasanlar T (1988): Triticale. Bilim ve Teknik Dergisi, 21-2479:40-42.

17. Geren H (2014): Dry matter yield and silage quality of some winter cereals harvested at different stages under mediterranean climate conditions. Turk J Field Crops, 19(2), 197-202.

18. Goering HK, Van Soest PJ (1983): Forage Fiber Analyses. Agricultural Handbook, No 379, Washington.

19. Gregory RS (1974): Hexaploid Triticales. Plant Breeding Institute, Cambridge. Annual Report. Cambridge UK, Plant Breeding Institute. 85-86.

20. Hackett R, Burke JI (2004): Potential for triticale in low cost production systems. National Tillage Conference, Wednesday, $28^{\text {th }}$ January, 90-104. 
21. Kaplan M, Kökten K, Akçura M (2014): Determination of silage characteristics and nutritional values of some triticale genotypes. Türk Tarım ve Doğa Bilimleri Dergisi, 1(2), 102-107.

22. Karabulut A, Canbolat O, Kamalak A (2006): Effect of maturity stage on the nutritive value of birdsfoot trefoil (Lotus corniculatus L) hays. Lotus Newsletter, 36, 11-21.

23. Keleş G (2014): Farklı Gelişme Dönemlerinde Hasat Edilmiş Tritikale Hasılında Morfolojik Unsurların Besin Değeri. Hayvansal Üretim 55(1): 1-6.

24. Koç F, Coşkuntuna L (2003): Silo yemlerinde organik asit belirlemede iki farklı metodun karşılaştırılması. Journal of Animal Production, 44(2), 37-47.

25. Luther MR (1986): Effect of microbial inoculation of whole plant corn silage on chemical characteristics. Preservation and utilization by steers. J Animal Sci, (1), 67-73.

26. Martin CA, Maurer O (1973): Introduction, adaptation and selection of triticale at Apodaca, Nuevo Leon. In XIII Informe de investigation 1971-1972. Division de Ciencias Agropecvarias Maritimas, Instituto Technologico de Monterrey. Nuevo Leon, Mexico, 34-35.

27. McDonald P, Henderson AR, Heron SJE (1991): The Biochemistry of Silage. Second Edition. 340 p., Chalcombe Publication, Marlow, England.

28. McDonald P, Edwards RA, Greenhalgh JFD (1988): Animal Nutrition. 4th Edition. Longman Scientific and Technical. 543.

29. Nadeau E (2007): Effects of plant species, stage of maturity and additive on the feeding value of whole-crop cereal silage. J Sci Food Agric, 87, 789-801.

30. Nair J, Beattie AD, Christensen D, Yu P, McAllister T, Damiran DJ, .McKinnon J (2018): Effect of variety and stage of maturity at harvest on nutrient and neutral detergent fiber digestibility of forage barley grown in western Canada. Canadian J Animal Sci, 98(2):299-310.

31. Nursoy H, Deniz S, Demirel M, Denek N (2003): Süt olum döneminde biçilen kimi mısır hasıllarına üre ve melas katk1larının silaj kalitesi ile sindirilebilir kuru madde verimine etkisi. Türk J Vet Animal Sci, 27, 93-99.

32. Ozduven ML, Onal ZK, Koc F (2010): The effects of bacterial inoculants and/or enzymes on the fermentation, aerobic stability and in vitro dry and organic matter digestibility characteristics of triticale silages. Kafkas Unıv Vet Fak Derg, 16(5), 751-756.

33. Rustas BO, Bertilsson J, Martinsson K, Elverstedt T, Nadeau E (2011): Intake and digestion of wholecrop barley and wheat silages by dairy heifers. J Anim Sci, 89: 4131-4141.

34. Seale DR, Pahlow G, Spoelstra SF, Lindgren S, Dellaglio F, Lowe JF (1990): Methods for the microbiological analysis of silage. Proceeding of The Eurobac Conference, Uppsala, 147.

35. Soysal Mİ (1998): Biyometrinin Prensipleri (İstatistik I ve II Ders Notları). Tekirdağ Ziraat Fakültesi Yayın No:95, Ders Kitabı No: 64, Tekirdağ, 331.

36. SPSS (2006): SPSS 15 for Windows. SPSS Inc.

37. Sucu E, Aydoğan Çifci E (2016): Effects of lines and inoculants on nutritive value and production costs of triticale silages. R Bras Zootec, 45(7):355-364.

38. Supelco (1998): Analyzing fatty acids by packed column gas chromatography. Bulletin 856B. Sigma Aldrich, St. Louis, MO.

39. Temel S, Tan M (2002: A research on determination of seeding and cutting time in common vetch (Vicia sativa L.) under Erzurum conditions. Ataturk Univ Ziraat Fak Derg, 33 (4): 363-368.

40. Wallsten J (2008): Whole-crop cereals in dairy production: Digestibility, Feed Intake and Milk Production. Doctoral Thesis, Swedish University of Agricultural Sciences, Umea. 